\title{
Bio-concentration of Copper in the Oreochromis mossambicus and Safe Level of Consumption
}

\author{
Budiyono Budiyono $^{1 凶}$, Ailsa Devina Rosahada ${ }^{2}$, Nikie Astorina Yunita Dewanti ${ }^{3}$ \\ ${ }^{1,2,3}$ Department of Environmental Health, Faculty of Public Health, Diponegoro University, Indonesia
}

\begin{tabular}{l} 
Article Info \\
\hline Article History: \\
Submitted February 2020 \\
Accepted November 2020 \\
Published January 2021 \\
\hline Keywords: \\
bio-concentration, copper, \\
Oreochromis mossambicus, \\
safe level \\
\hline DOI \\
https://doi.org/10.15294/ \\
ujph.v10i1.37786 \\
\hline
\end{tabular}

\begin{abstract}
Copper (Cu) is a heavy metal that is absorbed by organisms, such as Oreochromis mossambicus fish. This research aims to measure the bio-concentration of $\mathrm{Cu}$ in Oreochromis mossambicus and to predict the daily consumption of the fish. Samples of Oreochromis mossambicus fish were obtained from fishermen and collectors. The Cu concentration in the water and 30 fish was identified using the Atomic Absorption Spectrophotometry method. Questionnaires were employed to identify the demographic data of 101 respondents. The average concentration of $\mathrm{Cu}$ in the Oreochromis mossambicus fish and Rawapening Lake's water was $0.063 \mathrm{mg} / \mathrm{l}$ and $0.6 \mathrm{mg} / \mathrm{kg}$, respectively. Furthermore,

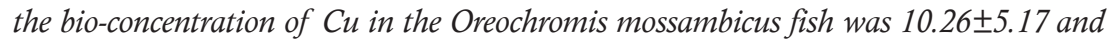
categorized as low, while the average daily consumption of fish was $225 \pm 36.89 \mathrm{~g} /$ day. Therefore, it was concluded that the average bio-concentration and the daily consumption of the fish are in the low and safe category respectively.
\end{abstract}

\section{INTRODUCTION}

The water sources in Rawapening Lake are from the rainwater, groundwater, and the river flow originating from the nine sub-watersheds (Kementerian Lingkungan Hidup Republik Indonesia, 2011). The activities of the people around the watersheds and Rawapening Lake such as wood industry, plantations, paddy irrigation, household waste disposal, fisheries, and tourism could cause the contamination of heavy metals Copper $(\mathrm{Cu})$ in the lake water (Piranti et al., 2018). Based on the previous research, it was found that the content of heavy metals $\mathrm{Cu}$ in the lake water was $2.032 \mathrm{mg} / 1$ and the standard quality in Indonesia was $0.02 \mathrm{mg} / 1$ (Peraturan Pemerintah, 2001; Hidayah et al., 2012). According to
ATSDR (Agency for Toxic Substances and Disease Registry), the content of $\mathrm{Cu}$ in the surface water (lake and river) was obtained with the median value of $10 \mathrm{ppb}$ (Agency for Toxic Substances and Disease Registry, 2004). The previous research found that the level of $\mathrm{Cu}$ in the water of Rawapening Lake was $0.063 \mathrm{mg} / 1$. This research discovered that there was an increase of $\mathrm{Cu}$ level in the water of Rawapening Lake compared with the previous studies which obtained the level of $\mathrm{Cu}$ at $0.049 \mathrm{mg} / 1$ (Hidayah et al., 2012).

The contamination of $\mathrm{Cu}$ in the water of Rawapening Lake can be accumulated in the organisms and the ecosystem on it, including the fish. The accumulation could happen directly by entering through gills and skins or known as bio-

\footnotetext{
$\triangle$ Correspondence Address:

Department of Environmental Health, Faculty of Public Health,

Diponegoro University, Indonesia

E-mail: budiyonofkm@lecturer.undip.ac.id
}

Open eISSN 2548-7604 
concentration, or indirectly or known as bio-magnification through the oral route (Ali et al., 2019)

The Oreochromis mossambicus fish is a carnivorous fish, so in the Rawapening Lake ecosystem, it is on the trophic level one. Besides eating plants, worms, and planktons, this $O$. mossambicus fish is also eating the smaller fishes. It causes the accumulation of heavy metals in the $O$. mossambicus becomes higher. The heavy metals entering the body of the fish will be accumulated in a long time (Mukhtasor, 2007).

The O. mossambicus fish is the majority of fish caught by the fishermen in the Rawapening Lake. The $O$. mossambicus fish caught by the fishermen are sold to the people in this area to be consumed. Therefore, the $\mathrm{Cu}$ contains in the fish will be transferred into the human body. Then, the $\mathrm{Cu}$ will quickly enter the bloodstream and distribute it to the whole body. Although $\mathrm{Cu}$ is one of the essential metals needed by the human for the metabolism in the hemoglobin and could be excreted through hair, sweat, menstruation, feces, and urine, this process could take a long time, thus the heavy metals can be accumulated in the body tissue especially in the liver and kidneys (Jaishankar et al., 2014). Therefore, if the concentration of $\mathrm{Cu}$ entering the body is high, the $\mathrm{Cu}$ will be poisonous in the body since it is hard to excrete (WHO, 2000). The measurement of the bio-concentration value of $\mathrm{Cu}$ is needed to know the level of accumulation in the Oreochromis mossambicus fish in Rawapening Lake and predict the amount of safe fish consumption for the people around the Rawapening Lake. This research is important in efforts to prevent exposure to $\mathrm{Cu}$ and can be used to analyze health risks in humans who consume this fish.

\section{METHODS}

The research was an exploratory study aimed to know the level of $\mathrm{Cu}$ in the water and $O$. mossambicus fish.

\section{Location}

The site of this research was in the Rawapening Lake spread in four villages of Semarang district (Tuntang: Cikal; Rowoboni: Muncul; Asinan: Krajan; Bejalen: Tambakrejo). The Rawapening Lake is a lake located in 455-465 meters above the sea level and astronomically located in the coordinate of $7^{\circ} 4^{\prime}-7^{\circ} 30^{\prime}$ South Latitude and $110^{\circ} 24^{\prime} 46^{\prime \prime}-110^{\circ} 49^{\prime} 06$ East Longitude. This lake has an area of about $2770 \mathrm{Ha}$. Administratively, it is located in the area of Semarang District, Central Java, Indonesia. Rawapening Lake has a depth of $65 \mathrm{~cm}-550 \mathrm{~cm}$.

\section{Population and Sample Sample of respondent}

The respondents were 101 people residing in Tuntang (30 respondents), Rowoboni (20 respondents), Asinan (27 respondents), Bejalen (24 respondents). The respondents were the people residing near Rawapening Lake. The sampling was conducted using purposive sampling. Respondents were selected based on the area closest to the Rawapening Lake.

\section{Sample of the environment}

The population of objects in this study was all $O$. mossambicus fish and water in the Rawapening Lake. The samples in this study were 30 of O. mossambicus fish.

\section{Data Collection and Analyze}

The data were collected using interviews and questionnaires for sample subjects. The variables asked in the interview including the characteristics of the respondents such as gender, age, occupation, education, income, the amount of $O$. mossambicus fish consumption. Those data were used as the measurement of $\mathrm{Cu}$ intake of the respondents. Similarly, the age and body weight were used to measure the maximum consumption allowed.

For sample object, the $O$. mossambicus fish that was used as the samples were the wild ones or the one living outside of the karamba (fish farming pond). The fish used as the samples were the fish obtained from direct catch and which were available in the local market thus classified as fresh fish. The fish was obtained by buying it from the fish catcher or fish collector around the Rawapening Lake. The adult O. mossambicus fish were $15-20 \mathrm{~cm}$ long and weigh around $200-300$ grams. The measurement was conducted using scale and meter instruments. The fish that did not meet the criteria of weight and length were not used as samples. There is no different weight and length between male and female fish.

For the lake water was obtained by grab or temporary sample (Bartram \& Ballance, 1996) from three points of the lake area, they are in Bejalen village, the outlet point of Panjang River, and the inlet point of Tuntang River. The samples were taken in a cleaned bottle, and $1000 \mathrm{ml}$ were taken from each point. Then, the samples were put in the cold box and transported into the laboratory to be tested. The test of $\mathrm{Cu}$ content in the lake water using the Atomic Absorption Spectrophotometry (AAS) method (Kojuncu et al., 2010; Lemos et al., 2007; Gentscheva et al., 2012).

The test of heavy metal $\mathrm{Cu}$ concentration in the fish was conducted in the Laboratory of 
the Center for Industrial Pollution Prevention Technology (BBTPPI) Semarang and the Laboratory of the Center for Goods Quality Testing and Certification Surakarta by using AAS method. Bio-concentration factor or BCF (Arnot \& Gobas, 2006), obtained using the formulation below:

$$
\mathrm{BCF}=\mathrm{Ct} \div \mathrm{CW}
$$

Note: https://www.epa.gov/iris

$\mathrm{C}_{\mathrm{t}}=$ concentration of $\mathrm{Cu}$ in the Oreochromis mossambicus fish muscle

$\mathrm{C}_{\mathrm{w}}=$ concentration of $\mathrm{Cu}$ in the water where the organisms live

The fish obtained from the fish catcher, market and fish collector were taken into the laboratory. The scales of the fish were removed and cleaned before the muscles were taken, and the other parts were used to be analyzed. Before the test was conducted, 100-gram muscles were weighed. Then, it was pulverized and put into the clean jar. The test of $\mathrm{Cu}$ concentration in the fish muscle using the Atomic Absorption Spectrophotometry (AAS) method.

The calculation of the maximum consumption level of fish containing $\mathrm{Cu}$ was as follows (Lemos et al., 2007; Agency for Toxic Substance and Disease Registry, 2010): CRlim = $(\mathrm{RfD} \times \mathrm{BW}) / \mathrm{Cm}$. Reference dose or RfD was obtained from the USEPA as the determiner of maximum level of fish consumption. The reference dose $(\mathrm{mg} / \mathrm{kg}$-day $)$ of $\mathrm{Cu}=0.0371 \mathrm{mg} / \mathrm{kg}$-day (Lee et al., 2005). Body weight (BW) in $\mathrm{kg}$ was obtained from the survey of body weight measurement towards the male and female respondents. Meanwhile, the $\mathrm{Cm}$ was the level or average concentration of the $\mathrm{Cu}$ in the $O$. mossambicus fish muscle that was consumed $(\mathrm{mg} / \mathrm{kg})$.

\section{RESULTS AND DISCUSSION}

The maximum load volume is \pm 65 million $\mathrm{m} 3$, while the minimum load volume is \pm 25 million $\mathrm{m} 3$. The water sources of the Rawapening Lake are from the springs inside the lake and from the rivers flowing into the lake.

Some villages around Rawapening village produce fish from the fish catching in the lake. Asinan Village is the village with the highest fish production for $171,192 \mathrm{~kg} /$ year. The second village to produce a great number of fish is Bejalen Village with $103,372 \mathrm{~kg}$ /year. The third place is Rowoboni Village with a total production of $95,523 \mathrm{~kg} /$ year. The fourth with the total fish production of $90,054 \mathrm{~kg} /$ year is Tuntang Village.

\section{The respondents}

Based on the survey data from 101 respondents, there were 28 male respondents and 73 female respondents. The median value of res- pondents' age was $24 \pm 3.5$ years old with the age range of 20-30 years old. The average bodyweight was $55.7 \pm 7.0 \mathrm{~kg}$ with the body weight range of $42-72 \mathrm{~kg}$. If it was distinguished by the gender, the average body weight for the adult female was $53 \pm 5.6 \mathrm{~kg}$ with the range of $42-65 \mathrm{~kg}$ and the average body weight for the adult male was $63 \pm 5.1$ with the range of $54-72 \mathrm{~kg}$. The information on demography is vital and use to estimate the level of risk of consumption of fish containing $\mathrm{Cu}$.

\section{$\mathrm{Cu}$ concentration in the lake and in the fish}

\section{and the $B C F$ value}

The content of metal $\mathrm{Cu}$ in three points/ locations including Tuntang River inlet, Panjang River outlet, and the lake water in Bejalen Village showed that the content of $\mathrm{Cu}$ was around 0.02 $\mathrm{mg} / 1-0.11 \mathrm{mg} / \mathrm{l}$, the average content of $\mathrm{Cu}$ in the lake water was $0.063 \mathrm{mg} / \mathrm{l}$. The $\mathrm{Cu}$ concentration is above the Indonesian National Standard is $0.02 \mathrm{mg} / 1$ of water samples.

The content of $\mathrm{Cu}$ in $O$. mossambicus fish in Rawapening Lake was around $0.002-1.57 \mathrm{mg} /$ $\mathrm{kg}$ with a mean of $0.6 \pm 0.28 \mathrm{mg} / \mathrm{kg}$. There were only three samples of fish that did not exceed the standard quality of $\mathrm{Cu}$ in the food according to SNI (Indonesia National Standard) which was around $0.3 \mathrm{mg} / \mathrm{kg}$. The calculation data found that the $\mathrm{BCF}$ value in the $O$. mossambicus fish was around $0.032-24.92$ and the mean of $\mathrm{BCF}$ was 10.26 \pm 5.17 . The $B C F$ value was classified into the low level of BCF because it was $<100$. Therefore, it can be concluded that the accumulation level of $O$. mossambicus fish in Rawapening Lake towards the $\mathrm{Cu}$ was still low.

\section{The Safe Limit of Maximum Daily Consump- tion of the Fish}

The finding showed that the people residing around Rawapening Lake consumed $O$. mossambicus fish for $75-300$ grams a day. The mean of $O$. mossambicus fish consumption was $225 \pm 36.89 \mathrm{gram} /$ day. Based on the provision of the US Environmental Protection Agency (USE$\mathrm{PA}$ ), the Reference Dose (RfD) value of $\mathrm{Cu}$ was used as the determination of maximum fish consumption (Agency for Toxic Substances and Disease Registry, 2004). The maximum limit of fish consumption was measured based on the bodyweight of the respondents. Based on the measurement, it was found that the maximum limit of fish consumption for adult females was $3.28 \mathrm{~kg} /$ day, while the maximum limit of fish consumption for adult males was $3.90 \mathrm{~kg} /$ day. Based on the total consumption of the people residing around Rawapening Lake, it is categorized in the safe level. 


\section{The potential sources of $\mathrm{Cu}$ in Rawapening} Lake

Rawapening Lake is located in a lower area and surrounded by hills and highlands, thus the water flow from those areas will flow into the lake. The content of $\mathrm{Cu}$ in the water of Rawapening Lake is suspected to be caused by the waste from several activities such as farming and plantation, household activities, livestock, hospitality, and hospital. According to Zaidi et al. (2019), the increase of $\mathrm{Cu}$ concentration in the water's ecosystem could happen naturally as a result of human activities (Agency for Toxic Substances and Disease Registry, 2004; Zaidi et al, 2019). The plantation around Rawapening Lake such as coffee, cocoa, tea, banana, and orange plantations used pesticides. The pesticides used for plantation and farming activities such as fungicides and herbicides were proven to contain $\mathrm{Cu}$ (Zaidi et al, 2019; Liu et al., 2007; Kuehne et al., 2017). The livestock activities such as dairy cows, pigs, goats, and sheep produced cattle manure and it contains a quite high level of $\mathrm{Cu}$ from the animal feed containing Cu (Norell, 2005; Xu et al., 2013; Panagos et al., 2018). Similarly with the human waste (Taylor et al., 2020) and the use of fertilizer in the agricultural around the Rawapening Lake that were suspected as the main factors causing the fluctuation of $\mathrm{Cu}$ contents in the water of $\mathrm{Ra}$ wapening Lake. It was because the fertilizer contained $\mathrm{Cu}$ (Malhi \& Karamanos, 2006). The nonhousehold activities that have the potential for $\mathrm{Cu}$

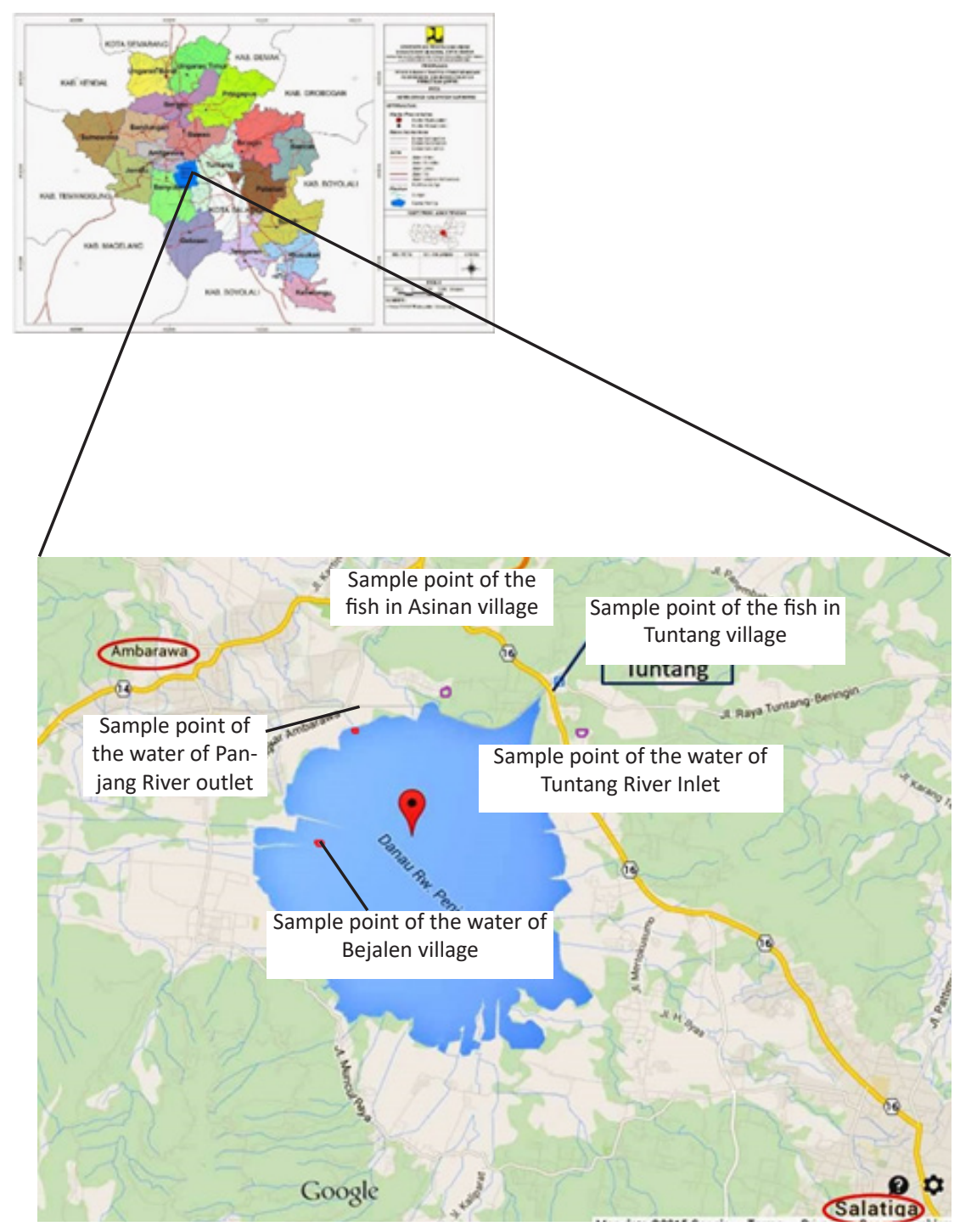

Figure 1 Location Points of Sampling 
contamination in Rawapening Lake include the hospitality and hospital through the laundry activity. The detergent used in the laundry/washing produced heavy metals such as $\mathrm{Cu}$ (Aonghusa \& Gray, 2002).

The important factors determining the fate of $\mathrm{Cu}$ in the water environment are the interaction between metal and the physical and chemical properties of water. Another study found that the order of metal concentration in the water was as follows: $\mathrm{Fe}>\mathrm{Zn}>\mathrm{Cu}>\mathrm{Mn}>\mathrm{Ni}>\mathrm{Cr}$ (Licona \& Negrete, 2019). The characteristics of the water in the river and lake are different and very dependent on the geochemistry of the location. Almost all $\mathrm{Cu}(>99.99 \%)$ are strongly bound by the ligand in the river water (Kiaune \& Singhasema- non, 2011), both inorganic and organic ligands such as dissolved organic materials. The $\mathrm{Cu}$ in the water is bounded by the natural organic materials dissolved in the water (Hullebusch et al., 2003). Therefore, the more organic materials dissolved in the water, the higher the concentration of the $\mathrm{Cu}$ (Louis et al., 2009). The Rawapening Lake contains many organic materials since the water sources are coming from the household, agricultural, and livestock activities. Moreover, many hyacinths grow in this lake, thus it produces organic materials dissolved in the water. The $\mathrm{Cu}$ concentration in the Rawapening Lake which is exceeding the threshold value is may cause by the bounding of $\mathrm{Cu}$ by the organic materials dissolved in the water. Furthermore, the concentrati-

Table 1. Concentration and Bio-concentration (BCF) of $\mathrm{Cu}$ in the O. mossambicus fish in Rawapening Lake

\begin{tabular}{|c|c|c|c|c|}
\hline Sample Code & Fish Weight (gram) & Long $(\mathrm{cm})$ & $\mathrm{Cu}$ Concentration $(\mathrm{mg} / \mathrm{kg})$ & $\mathrm{BCF}$ \\
\hline A-1 & 230 & 17.5 & 0.574 & 9.1 \\
\hline A-2 & 280 & 18.6 & 1.043 & 16.6 \\
\hline A-3 & 210 & 16.4 & 1.153 & 18.3 \\
\hline A-4 & 300 & 20 & 0.634 & 10.1 \\
\hline A-5 & 250 & 18.2 & 0.289 & 4.6 \\
\hline A-6 & 200 & 16.5 & 0.945 & 15 \\
\hline A-7 & 300 & 20 & 0.387 & 6.14 \\
\hline A-8 & 250 & 18.5 & 0.368 & 5.84 \\
\hline B-1 & 220 & 18.5 & 0.26 & 4.13 \\
\hline B-2 & 240 & 19.8 & 0.93 & 14.76 \\
\hline B-3 & 235 & 19 & 0.88 & 13.97 \\
\hline B-4 & 300 & 20 & 0.59 & 9.37 \\
\hline B-5 & 260 & 18.9 & 0.68 & 10.79 \\
\hline B-6 & 215 & 19.4 & 0.49 & 7.78 \\
\hline B-7 & 200 & 17.8 & 0.39 & 6.19 \\
\hline B-8 & 205 & 17.9 & 0,36 & 5.71 \\
\hline B-9 & 215 & 18.5 & 0.81 & 12.86 \\
\hline B-10 & 230 & 19.5 & 0.38 & 6.03 \\
\hline B-11 & 205 & 18.4 & 0.33 & 5.24 \\
\hline B-12 & 200 & 18 & 0.80 & 12.7 \\
\hline B-13 & 220 & 20 & 0.44 & 6.99 \\
\hline B-14 & 290 & 20 & 0.97 & 15.87 \\
\hline B-15 & 200 & 18 & 1.57 & 24.92 \\
\hline B-16 & 230 & 18.4 & $<0.002$ & 0.032 \\
\hline B-17 & 200 & 17.5 & 0.90 & 14.29 \\
\hline B-18 & 200 & 17.5 & 0.63 & 10 \\
\hline B-19 & 300 & 20 & 0.34 & 5.6 \\
\hline B-20 & 205 & 18 & 0.74 & 11.75 \\
\hline B-21 & 300 & 20 & 0.74 & 11.75 \\
\hline B-22 & 260 & 20 & 0.74 & 11.75 \\
\hline
\end{tabular}


on of heavy metal $\mathrm{Cu}$ in the water is also affected by $\mathrm{pH}$, temperature, and alkalinity. The degree of acidity of the water $(\mathrm{pH})$ showed a positive correlation towards the $\mathrm{Cu}$ concentration in the water, as well as the temperature and the alkalinity (Okpashi et al, 2018).

Bio-concentration factor (BCF) is the ability of organisms in accumulating the chemical materials or pollutant in their bodies. BCF can also be defined as the ratio between the concentration of pollutant in the organism body layers $\left(C_{t}\right)$ and the concentration of chemical materials in the water where the organisms live $\left(\mathrm{C}_{\mathrm{w}}\right)$ (Adolfsson-Erici et al., 2012). This study found that the $\mathrm{Cu}$ concentration in the Oreochromis mossambicus fish was low. The metal in the natural water could be in a form of particles and dissolved. There are several factors affecting the uptake and accumulation of the metals in the fish such as the water temperature, in which the high temperature affected the uptake speed of the metals such as $\mathrm{Cu}$. According to previous study the water temperature in Rawa Pening lake was $31-32^{\circ} \mathrm{C}$ (Piranti et al., 2018). The temperature supports the uptake of the $\mathrm{Cu}$ in the fish faster. Similarly, the water condition with low $\mathrm{pH}$ or acid also affects the accumulation of metals in the water. However, the hardness of water and existence of carbonate could decrease the uptake of the heavy metals to the fish (Jezierska \& Witeska, 2007). The accumulation of metal in the fish muscle, gills, and liver showed the order of accumulation as follows: $\mathrm{Fe}>\mathrm{Zn}>\mathrm{Cu}>\mathrm{Mn}>\mathrm{Pb}>\mathrm{Cd}$. However, the characteristics of $\mathrm{pH}$, temperature and alkalinity did not affect the accumulation of $\mathrm{Cu}$ in the fish (Okpashi et al, 2018). Another research found that the order of heavy metals concentration in the fish muscle was $\mathrm{Zn}>\mathrm{As}>\mathrm{Cu}$ $>\mathrm{Mn}>\mathrm{Cr}>\mathrm{Ni}>\mathrm{Cd}>\mathrm{Co}>\mathrm{Pb}$ (Alkan et al., 2016). Meanwhile, another research found that the concentration of metals in the fish muscle was in the following order: $\mathrm{Fe}>\mathrm{Zn}>\mathrm{Cu}>\mathrm{Mn}$ $>\mathrm{Pb}>\mathrm{Cd}$ (Miller, et al., 2013). Therefore, from those two studies it can be said that the metals concentration of $\mathrm{Fe}, \mathrm{Zn}$, and $\mathrm{Cu}$ were dominant in the fish muscle. Several studies found that the accumulation of $\mathrm{Cu}$ was the highest in the gills and liver (Dobrochna et al., 2018) and the metals concentration was increased in the gills. It was because the gills that were contaminated by $\mathrm{Cu}$ would produce mucus as a protection metabolism and with the increase of mucus there will be a $\mathrm{Cu}$ bound. From the gills, it would be transferred into the liver, while the muscles were not effective in this metals bound (Tunçsoy \& Erdem, 2014). Even another study found that there was no $\mathrm{Cu}$ found in the muscle from the experiment (Santarossa, et al., 2018).

Besides the physical and chemical factors of the water in affecting the uptake rate of $\mathrm{Cu}$ in the fish, the age and size of the fish were also affecting the metals accumulation. In this research, the weight and length of the fish had normal distribution ( $p=0.452$ and $p=0.482$ ); however, the size of the fish was not correlated with the $\mathrm{Cu}$ concentration in the fish muscle $(p>0.05)$. This research was contradicted with the previous studies which found that the size of the fish had a positive correlation with the $\mathrm{Cu}$ concentration in the fish. The big fish had a higher $\mathrm{Cu}$ concentration in its muscles (Yi \& Zhang, 2012). The concentration of $\mathrm{Cu}$ in the water was strongly correlated with the concentration of $\mathrm{Cu}$ in the fish muscles (Licona \& Negrete, 2019).

The daily consumption of fish containing $\mathrm{Cu}$ was still in the safe limit, but the consumption of the food containing $\mathrm{Cu}$ in a long term could cause health problems such as Wilson disease, severe autosomal disorders, recessive genetic disease (Araya et al., 2007). Moreover, according to $\mathrm{WHO}$, the exposure of metals through oral at $0.011 \mathrm{mg} / \mathrm{kg}$ could cause the symptoms of gastrointestinal problems such as nausea, vomit, diarrhea, and abdominal cramp. Those symptoms would arise when the exposure happened in 1-2 week (WHO, 2000). The indicator of the bioaccumulation of the $\mathrm{Cu}$ in the human body is useful for the health risk assessment related to the diseases.

\section{CONCLUSION}

The average of bio-concentration is in a low category and the daily consumption of the fish is in a safe category. Although it is within safe levels for consumption, further research is needed regarding the presence of $\mathrm{Cu}$ in the human body. Furthermore, it is necessary to manage waste generating from the activities of residents around the lake.

\section{REFERENCES}

Adolfsson-Erici, M., Åkerman, G. \& Mclachlan, M. S. 2012. Measuring Bioconcentration Factors in Fish Using Exposure to Multiple Chemicals and Internal Benchmarking to Correct for Growth Dilution. Environmental Toxicology and Chemistry, 31 (8): 1853-1860. doi: 10.1002/ etc.1897. https://pubmed.ncbi.nlm.nih. gov/22639194/

Agency for Toxic Substance and Disease Registry. 2010. Guidance for Assessing Chemical Contaminant Data for Use in Fish Advisories. USA: Environmental Protection Agency (EPA). https:// 
www.epa.gov/fish-tech/guidance-assessingchemical-contaminant-data-use-fish-advisories-documents

Agency for Toxic Substances and Disease Registry. 2004. Toxicology Profile for Copper. USA: Department of Health and Human Services. https:// www.atsdr.cdc.gov/toxprofiles/tp132.pdf

Ali, H., Khan, E. \& Ilahi, I. 2019. Environmental Chemistry and Ecotoxicology of Hazardous Heavy Metals: Environmental Persistence, Toxicity, and Bioaccumulation. Journal of Chemistry, 2019(Cd). doi: 10.1155/2019/6730305. https://www.hindawi.com/journals/ jchem/2019/6730305/

Alkan, A., Alkan, N. \& Akbaș, U. 2016. The factors affecting heavy metal levels in the muscle tissues of whiting (Merlangius merlangus) and red mullet (Mullus barbatus). Tarm Bilimleri Dergisi, 22 (3): 349-359. https://doi.org/10.1501/ Tarimbil 0000001393

Aonghusa, C. N. \& Gray, N. F. 2002. Laundry Detergents as a Source of Heavy Metals in Irish Domestic Wastewater. Journal of Environmental Science and Health - Part A Toxic/Hazardous Substances and Environmental Engineering, 37 (1): 1-6. https://doi.org/10.1081/ESE-100108477

Araya, M., Olivares, M. \& Pizarro, F. 2007. Copper in Human Health. International Journal of Environment and Health, 1 (4): 608-620. https://doi. org/10.1504/IJENVH.2007.018578

Arnot, J. A. \& Gobas, F. A. P. C. 2006. A Review of Bioconcentration Factor (BCF) and Bioaccumulation Factor (BAF) Assessments for Organic Chemicals in Aquatic Organisms. Environmental Reviews, 14 (4): 257-297. https://doi. org/10.1139/A06-005

Bartram, J. \& Ballance, R. 1996. Water Quality Monitoring - A Practical Guide to the Design and Implementation of Freshwater Quality Studies and Monitoring Programmes. WHO. https://apps.who.int/ iris/handle/10665/41851

Dobrochna, A., Jerzy, S., Teresa, O., Magda, F., Malgorzata, R., Yuichiro, M., Kacper, M. 2018. Effect of copper and silver nanoparticles on trunk muscles in Rainbow Trout (Oncorhynchus mykiss, Walbaum, 1792). Turkish Journal of Fisheries and Aquatic Sciences, 18 (6): 781-788. https://doi.org/10.4194/1303-2712-v18 604

Gentscheva, G., Petrov, A., Ivanova, E., \& Havezov, I. 2012. Flame AAS Determination of Trace Amounts of $\mathrm{Cu}, \mathrm{Ni}, \mathrm{Co}, \mathrm{Cd}$ and $\mathrm{Pd}$ in Waters After Preconcentration with 2-Nitroso-1-Naphthol. Bulgarian Chemical Communications, 44 (1): 52-56. http://bcc.bas.bg/BCC Volumes/Volume 44 Number 1 2012/Volume 44 Number 12012 PDF/BCC-44-1-2012 7.pdf

Hullebusch, E. V., Auvray, F., Bordas, F., Deluchat, V., Chazal, P. M., \& Baudu, M. 2003. Role of Organic Matter in Copper Mobility in a Polymictic Lake Following Copper Sulfate Treatment (Courtille Lake, France). Environmental Technology (United Kingdom), 24 (6): 787-796. https:// doi.org/10.1080/09593330309385615

Jaishankar, M., Tseten, T., Anbalagan, N., Mathew, B.B., \& Beeregowda, K.N. 2014. Toxicity, Mechanism and Health Effects of Some Heavy Metals. Interdisciplinary Toxicology, 7 (2): 60-72. https://doi.org/10.2478/intox-2014-0009

Jezierska, B. \& Witeska, M. 2007. The Metal Uptake and Accumulation in Fish Living in Polluted Waters. Soil and Water Pollution Monitoring, Protection and Remediation. NATO Science Series, 69. https://doi.org/10.1007/978-14020-4728-2 6

Licona, V. \& Negrete, M. 2019. Mercury, Methylmercury and Other Heavy Metals in Fish in Colombia: Risk from Ingestion. Acta Biologica Colombiana, 24 (2): 232-242. http://dx.doi. org/10.15446/abc.v24n2.74128

Kiaune, L. \& Singhasemanon, N. 2011. Pesticidal Copper (I) Oxide: Environmental Fate and Aquatic Toxicity. Reviews of Environmental Contamination and Toxicology, 213: 1-26. https:// doi.org/10.1007/978-1-4419-9860-6 1

Kojuncu, Ý., Bundalevska, J.M., Ay, U., Cundeva, K., Stafilov, T. \& Akcin, G. 2010. Atomic Absorption Spectrometry Determination of $\mathrm{Cd}, \mathrm{Cu}$, $\mathrm{Fe}, \mathrm{Ni}, \mathrm{Pb}, \mathrm{Zn}$, and $\mathrm{T} 1$ Traces in Seawater Following Flotation Separation. Separation Science and Technology, 39 (11): 2751-2765. https:// doi.org/10.1081/SS-200026751

Kuehne, S. et al. 2017. The Use of Copper Pesticides in Germany and the Search for Minimization and Replacement Strategies. Organic Farming, 3 (1). https://doi.org/10.12924/of2017.03010066

Lee, J. S., Chon, H. T. \& Kim, K. W. 2005. Human Risk Assessment of $\mathrm{As}, \mathrm{Cd}, \mathrm{Cu}$ and $\mathrm{Zn}$ in the Abandoned Metal Mine Site. Environmental Geochemistry and Health, 27(2): 185-191. https://doi.org/10.1007/s10653-005-0131-6

Lemos, V. A., Santos, M.S., Santos, M.J.S., Vieira, D.R. \& Novaes, C.G. 2007. Determination of Copper in Water Samples by Atomic Absorption Spectrometry After Cloud Point Extraction. Mikrochimica Acta, 157 (3-4): 215-222. https://doi.org/10.1007/s00604-006-0652-4

Liu, T.F., Sun, C., Ta, N., Hong, J., Yang, S., Chen, Chuan-xiang. 2007. Effect of Copper on the Degradation of Pesticides Cypermethrin and Cyhalothrin. Journal of Environmental Sciences, 19 (10): 1235-1238. https://doi.org/10.1016/ $\underline{\mathrm{S} 1001-0742(07) 60201-0}$

Louis, Y. et al. 2009. Kinetic and Equilibrium Studies of Copper-Dissolved Organic Matter Complexation in Water Column of the Stratified Krka River Estuary (Croatia). Marine Chemistry, 114 (3-4): 110-119. https://doi.org/10.1016/j. marchem.2009.04.006

Hidayah, A.M., Purwanto, \& Soeprobowati, T.R. 2012. Kandungan Logam Berat Pada Air, Sedimen dan Ikan Nila (Oreochromis niloticus Linn.) di Karamba Danau Rawapening. Presented in Prosiding Seminar Nasional Pengelolaan 
Sumberdaya Alam dan Lingkungan. Semarang, 11 September 2012. http://eprints.undip. ac.id/37620/1/015-Anny.pdf

Malhi, S. S. \& Karamanos, R. E. 2006. A Review of Copper Fertilizer Management for Optimum Yield and Quality of Crops in the Canadian Prairie Provinces. Canadian Journal of Plant Science, 86 (3): 605-619. https://doi.org/10.4141/ $\underline{\mathrm{P} 05-148}$

Miller, I. S., Petukhov, V. L., Korotkevich, O. S., Korotkova, G. N. \& I. S. Konovalov. 2013. Accumulation of Heavy Metals in the Muscles of Zander from Novosibirsk Water Basin. E3S Web of Conferences, 1: 7-9. https://doi.org/10.1051/ e3sconf $/ 20130111007$

Mukhtasor. 2007. Pencemaran Pesisir dan Laut. Jakarta: Pradnya Paramita. https://opac.perpusnas. go.id/DetailOpac. aspx?id=39386

Norell, R. J. 2005. The Wisconsin System for Evaluating Corn Silage. Proceedings of the 2005 Idaho Alfalfa and Forage Conference, (February): 44-51.

Okpashi, V.E., Ogugua, V.N., Ubani, C.S., \& Juliet, N.O. 2018. An Evaluation of Contaminant Body Burdens in Selected Fish Species: Associating Toxicity to Upgrade the Hazard Assessment. Jordan Journal of Biological Sciences, 11(2), pp.171177. https://www.researchgate.net/profile/ Victor Okpashi/publication/325882534 An evaluation of contaminant body burdens in selected fish species Associating toxicity to upgrade the hazard assessment/ links/5cf71179a6fdcc84750639ef/An-evaluation-of-contaminant-body-burdens-in-selectedfish-species-Associating-toxicity-to-upgradethe-hazard-assessment.pdf

Panagos, P. et al. 2018. Potential Sources of Anthropogenic Copper Inputs to European Agricultural Soils. Sustainability (Switzerland), 10 (7): 1-17. https://doi.org/10.3390/su10072380.

Piranti, A.S., Rahayu, D. R. U. S., \& Waluyo, G. 2018. Evaluasi Status Mutu Air Danau Rawa Pening. Jurnal Pengelolaan Sumberdaya Alam dan Lingkungan, 8 (2): 151-160. https://doi. org/10.29244/jps1.8.2.151-160

Santarossa, M. A. da S., Tintor, D.G., Dourado, T. de A., Jotta, C.A.D., Menegario, A.A., \& Ferreira, J.R. 2018. Copper and Cadmium Ac- cumulation in Gills and Muscular Tissue of Tilapia (Oreochromis Niloticus) Under Experimental Conditions. Boletim do Instituto de Pesca, 44 (3): 1-11. https://doi.org/10.20950/16782305.2018 .332

Taylor, A. A. et al. 2020. Critical Review of Exposure and Effects: Implications for Setting Regulatory Health Criteria for Ingested Copper. Journal of Environmental Management, 65 (1): 131-159. https://doi.org/10.1007/s00267-019-01234-y

Tunçsoy, M. \& Erdem, C. 2014. Accumulation of Copper, Zinc and Cadmium in Liver, Gill and Muscle Tissues of Oreochromis Niloticus Exposed to these Metals Separately and in Mixture. Fresenius Environmental Bulletin, 23 (5): 11431149. https://www.researchgate.net/profile/ Mustafa Tuncsoy/publication/262423713 Accumulation of copper zinc and cadmium in liver gill and muscle tissues of Oreochromis niloticus exposed to these metals separately and in mixture/ links/0a85e537b647b6131b000000.pdf

WHO. 2000. Copper in Drinking Water, Copper in Drinking Water. New York: The National Academies of Scinces Engineering Medicine. https://doi. org/10.17226/9782

Xu, Y., Yu, W., Ma, Q., \& Zhou, H. 2013. Accumulation of Copper and Zinc in Soil and Plant Within Ten-Year Application of Different Pig Manure Rates. Plant, Soil and Environment, 59 (11): 492-499. https://doi.org/10.17221/121/2013pse

Yi, Y. J. \& Zhang, S. H. 2012: The Relationships between Fish Heavy Metal Concentrations and Fish Size in the Upper and Middle Reach of Yangtze River. Procedia Environmental Sciences, 13 (2011): 1699-1707. https://doi. org/10.1016/j.proenv.2012.01.163

Zaidi, A.A., Baig, M.B., Muneer, S.E., Hussain, S.M., \& Aldosari, F.O. 2019. Farmers' Level of Knowledge on the Usage of Pesticides and Their Effects on Health and Environment in Northern Pakistan. Journal of Animal and Plant Sciences, 29 (6): 1718-1732. http://www.thejaps.org.pk/docs/Accepted/2019/29-06/32. pdf 